CORRECTION

\title{
Correction to: Silencing long non-coding RNA CASC9 inhibits colorectal cancer cell proliferation by acting as a competing endogenous RNA of miR-576-5p to regulate AKT3
}

Hui-Zi Liu (D), Ti-Dong Shan, Yue Han and Xi-Shuang Liu

(c) The Author(s) 2021

Cell Death Discovery (2021)7:185 ; https://doi.org/10.1038/s41420-021-00564-3

Correction to: Cell Death Discovery https://doi.org/10.1038/s41420020-00352-5, published online 31 October 2020

Since publication of this article, the authors noticed that an incorrect image was used in Figure 3a si-NC/HT29 panel. The corrected image is shown below. The authors apologise for any inconvenience caused by this error. The original article has been corrected.

\begin{abstract}
(c) (i) Open Access This article is licensed under a Creative Commons Attribution 4.0 International License, which permits use, sharing, appropriate credit to the original author(s) and the source, provide a link to the Creative Commons license, and indicate if changes were made. The images or other third party material in this article are included in the article's Creative Commons license, unless indicated otherwise in a credit line to the material. If material is not included in the article's Creative Commons license and your intended use is not permitted by statutory regulation or exceeds the permitted use, you will need to obtain permission directly from the copyright holder. To view a copy of this license, visit http://creativecommons. org/licenses/by/4.0/.
\end{abstract}

(c) The Author(s) 2021
Fig. 3.

a

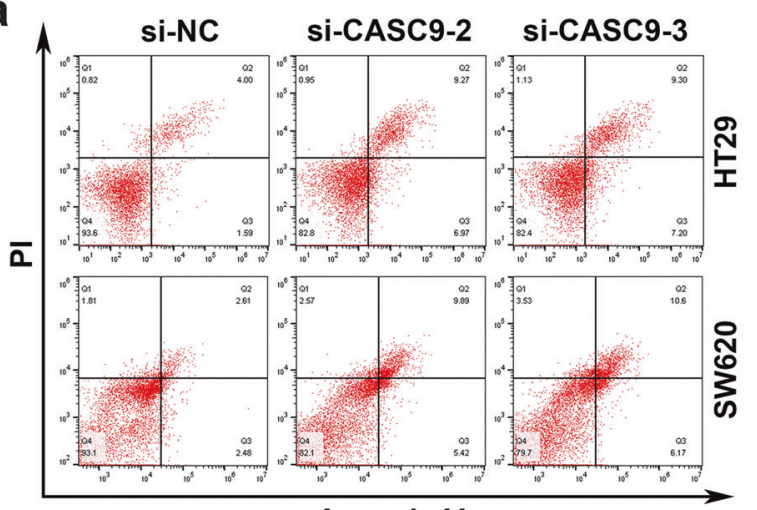

Annexin V

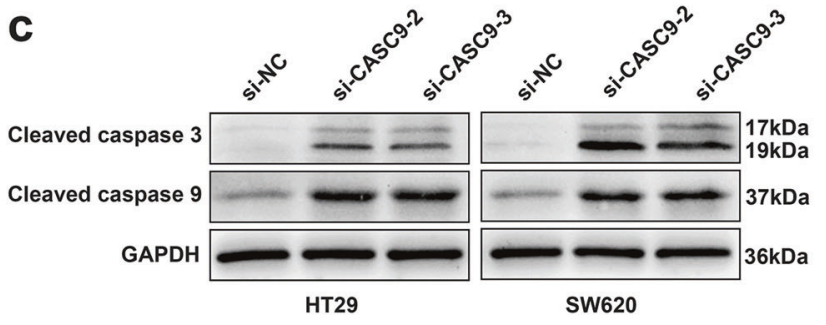

b

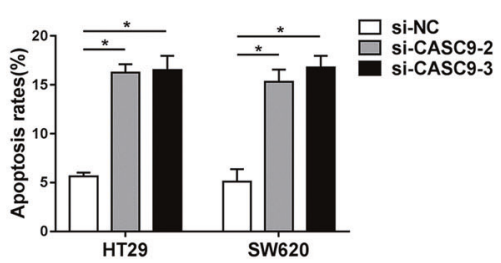

d
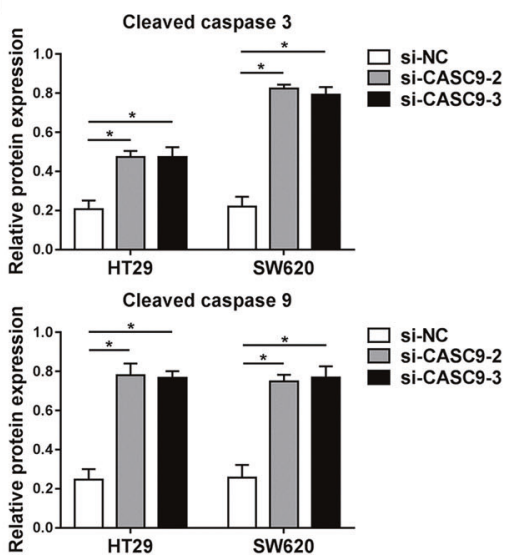